\title{
Enterobacter pyrinus sp. nov., an Organism Associated with Brown Leaf Spot Disease of Pear Trees
}

\author{
YOUNG RYUN CHUNG, ${ }^{1 *}$ DON J. BRENNER, ${ }^{2}$ ARNOLD G. STEIGERWALT, ${ }^{2}$ BYUNG SUP KIM, ${ }^{3}$ \\ HEUNG TAE KIM, ${ }^{3}$ AND KWANG YUN CHO ${ }^{3}$ \\ Department of Microbiology, Gyeongsang National University, Chinju 660-701, ${ }^{1}$ and Agrochemical Screening \\ Center, Korea Research Institute of Chemical Technology, Daejeon 305-606, ${ }^{3}$ Korea, and Meningitis and \\ Special Pathogens Branch, Division of Bacterial and Mycotic Diseases, National Center for Infectious \\ Diseases, Centers for Disease Control, Atlanta, Georgia $30333^{2}$
}

\begin{abstract}
A new species, Enterobacter pyrinus, which was isolated from brown leaf spot lesions on pear trees, is described on the basis of the characteristics of seven strains. These bacteria are gram-negative, facultatively anaerobic, straight rods $(0.6$ to 1.0 by 1.6 to $2.3 \mu \mathrm{m})$ that are motile and peritrichous. As determined by DNA hybridization (hydroxyapatite method), these seven strains were $97.5 \%$ related in both 60 and $75^{\circ} \mathrm{C}$ reactions, with no evidence of sequence divergence, indicating that they are members of a single species. $E$. pyrinus is most closely related to Enterobacter gergoviae (46\%) and to Enterobacter agglomerans hybridization group XI (37\%). $E$. pyrinus is differentiated from $E$. gergoviae by its growth in $\mathrm{KCN}$ broth, acid production from myo-inositol, and lack of acid production from raffinose. The type strain of $E$. pyrinus is strain KCTC 2520 (= CDC G6570 = ATCC 49851).
\end{abstract}

Brown leaf spot disease of pear trees was first observed in 1979 and has been epidemic since then in Korea, causing significant losses in pear yields (10). Recently, Chung et al. found that this disease is caused by gram-negative bacteria (8). These authors isolated the pathogenic bacteria from necrotic lesions of pear leaf spots and found them to be a new species that was similar to Erwinia species on the basis of morphological, physiological, and biochemical characteristics. The organism was named "Erwinia pirina" (8), although this name was never validated in the International Journal of Systematic Bacteriology and therefore has no standing in bacterial nomenclature.

Since the genus Erwinia is quite heterogeneous and since some species previously included in it have been transferred to the genus Enterobacter, it was necessary to further characterize the bacterial isolates from pears both biochemically and by DNA hybridization (4). In this paper we describe the results of these additional studies; on the basis of our results the name Enterobacter pyrinus sp. nov. is proposed for the agent of brown leaf spot disease of pears.

\section{MATERIALS AND METHODS}

Bacterial strains. A total of 28 strains were isolated from brown leaf spots of pear trees (Pyrus pyrifolia cv. Shingo and Mansamgil) in the Yusung area of Korea in 1988 (8). Seven of these strains, strains KCTC $2520^{\mathrm{T}}$ ( $\mathrm{T}=$ type strain), KCTC 2585, KCTC 2586, KCTC 2587, KCTC 2588, KCTC 2589, and KCTC 2590, were obtained from the Korean Collection for Type Cultures, Genetic Engineering Research Institute, Korea Institute of Science and Technology, Daejeon, Korea. Enterobacter dissolvens ATCC $23373^{\mathrm{T}}$, Erwinia rhapontici ATCC $29283^{\mathrm{T}}$, Erwinia ananas ATCC $33244^{\mathrm{T}}$, Erwinia chrysanthemi ATCC $11663^{\mathrm{T}}$, Erwinia stewartii ATCC $8199^{\mathrm{T}}$, and Klebsiella pneumoniae subsp. oxytoca ATCC $13182^{\mathrm{T}}$ were obtained from the American Type Culture Collection, Rockville, Md. Unless noted otherwise,

\footnotetext{
* Corresponding author.
}

all strains were maintained on medium containing $1 \% \mathrm{Ca}$ sitone (Difco Laboratories, Detroit, Mich.), $0.3 \%$ yeast extract, $0.5 \% \mathrm{NaCl}$, and $0.7 \%$ agar or on nutrient agar at $30^{\circ} \mathrm{C}$. All of the DNAs used in DNA hybridization experiments (Table 1) were obtained from strains in the culture collection of the Meningitis and Special Pathogens Laboratory Section, Centers for Disease Control, Atlanta, Ga. (4).

Phenotypic characteristics. The methods described by Schaad (14) were used for the following physiological and biochemical tests: catalase, oxidase, phosphatase, urease, indole production, acetoin production (Voges-Proskauer test), acid production from carbohydrates, utilization of organic compounds, $\mathrm{H}_{2} \mathrm{~S}$ production from cysteine, gelatin liquefaction, nitrate reduction, erythromycin susceptibility, growth at $36^{\circ} \mathrm{C}$, potato soft rot, and tobacco hypersensitivity. Phenylalanine deaminase activity, DNase activity, casein hydrolysis, and motility were tested as described by Smibert and Krieg (15). Mucoid growth was tested on nutrient agar containing 5\% sucrose, and tolerance to $5 \%$ $\mathrm{NaCl}$ was tested in nutrient broth. Tolerance to $\mathrm{KCN}$ was determined on Difco KCN broth. Commercial media were used whenever possible. Colonial characteristics and pigment formation were determined on nutrient agar. Cells and flagella were observed by phase-contrast light microscopy and electron microscopy. Inocula for biochemical and physiological tests were prepared from 24-h cultures grown on nutrient agar at $27^{\circ} \mathrm{C}$, unless indicated otherwise.

DNA methods. Guanine-plus-cytosine $(\mathrm{G}+\mathrm{C})$ contents were determined spectrophotometrically by the method of Marmur and Doty (13) and are reported below to the nearest $0.5 \mathrm{~mol} \%$. The methods used to extract and purify DNA and the hydroxyapatite hybridization method for determining levels of DNA relatedness have been described previously (5). Strain KCTC $2520^{\mathrm{T}}$ was labeled enzymatically in vitro with $\left[{ }^{32} \mathrm{P}\right] \mathrm{dCTP}$ by using a nick translation reagent kit (Bethesda Research Laboratories, Inc., Gaithersburg, Md.) as directed by the manufacturer. Each $\mathrm{G}+\mathrm{C}$ content determination and DNA hybridization reaction was done at least twice, and the values obtained were averaged. 
TABLE 1. Levels of DNA relatedness between Enterobacter pyrinus isolates and between Enterobacter pyrinus $\mathrm{KCTC} 2520^{\mathrm{T}}$ and representative strains of members of the Enterobacteriaceae

\begin{tabular}{|c|c|c|c|}
\hline \multirow[b]{2}{*}{ Source of unlabeled DNA ${ }^{a}$} & \multicolumn{3}{|c|}{ Labeled DNA from Enterobacter pyrinus KCTC $2520^{\mathbf{T}}$} \\
\hline & $\begin{array}{l}\text { Relative binding } \\
\text { ratio at } 60^{\circ} \mathrm{C}^{b}\end{array}$ & $\begin{array}{c}\% \\
\text { Divergence }^{b}\end{array}$ & $\begin{array}{l}\text { Relative binding } \\
\text { ratio at } 75^{\circ} \mathrm{C}\end{array}$ \\
\hline Enterobacter pyrinus $\mathrm{KCTC} 2520^{\mathrm{T}}$ & 100 & 0.0 & 100 \\
\hline Enterobacter pyrinus KCTC 2588 & 100 & 0.0 & 100 \\
\hline Enterobacter pyrinus KCTC 2586 & 99 & 0.0 & 99 \\
\hline Enterobacter pyrinus KCTC 2585 & 99 & 0.0 & 97 \\
\hline Enterobacter pyrinus KCTC 2589 & 97 & 0.0 & 96 \\
\hline Enterobacter pyrinus KCTC 2590 & 96 & 0.0 & 96 \\
\hline Enterobacter pyrinus KCTC 2587 & 94 & 0.0 & 97 \\
\hline Enterobacter gergoviae IP 76.01 & 46 & $-^{c}$ & \\
\hline Enterobacter agglomerans CDC 5378-71 & 37 & & \\
\hline Enterobacter gergoviae CDC 2863-76 & 34 & & \\
\hline Cedecea davisae CDC 3278-77 & 34 & & \\
\hline Enterobacter agglomerans CDC $4388-71$ & 33 & & \\
\hline Enterobacter aerogenes CDC $1627-66$ & 33 & & \\
\hline Enterobacter gergoviae CDC $607-77$ & 32 & & \\
\hline Escherichia vulneris CDC $2898-73$ & 32 & & \\
\hline Klebsiella pneumoniae CDC 2 & 29 & & \\
\hline Klebsiella terrigena CDC $9001-81$ & 29 & & \\
\hline Enterobacter dissolvens ATCC 23373 & 27 & & \\
\hline Enterobacter intermedius CDC $9001-82$ & 26 & & \\
\hline Enterobacter agglomerans CDC $2780-70$ & 26 & & \\
\hline Klebsiella pneumoniae subsp. rhinoscleromatis & 26 & & \\
\hline Enwinia milletiae CDC $9572-82$ & 26 & & \\
\hline Enwinia herbicola CDC $9571-82$ & 26 & & \\
\hline Erwinia persicinus CDC $9108-82$ & 25 & & \\
\hline Enterobacter agglomerans CDC $3123-70$ & 25 & & \\
\hline Enterobacter agglomerans CDC 219-71 & 25 & & \\
\hline Enterobacter agglomerans CDC 6003-71 & 24 & & \\
\hline Enterobacter nimipressuralis CDC 9912 & 24 & & \\
\hline Enterobacter sakazakii CDC $4562-70$ & 24 & & \\
\hline Enterobacter taylorae CDC $2126-81$ & 24 & & \\
\hline Klebsiella planticola CDC 4245-72 & 24 & & \\
\hline Cedecea lapagei CDC $485-76$ & 24 & & \\
\hline Kluyvera ascorbata CDC $408-78$ & 24 & & \\
\hline Erwinia rhapontici ATCC 29283 & 23 & & \\
\hline Enterobacter cloacae CDC 1347-71 & 23 & & \\
\hline Serratia marcescens CDC $868-57$ & 23 & & \\
\hline Erwinia amylovora EA178 & 22 & & \\
\hline Erwinia ananas ATCC 33244 & 22 & & \\
\hline Enterobacter agglomerans CDC 5422-69 & 22 & & \\
\hline Enterobacter amnigenus CDC 1325-74 & 22 & & \\
\hline Citrobacter freundii CDC 460-61 & 22 & & \\
\hline Salmonella typhimurium LT2 & 22 & & \\
\hline Klebsiella pneumoniae subsp. oxytoca ATCC 13282 & 22 & & \\
\hline Erwinia chrysanthemi ATCC 11663 & 21 & & \\
\hline Enterobacter agglomerans CDC 1741-71 & 21 & & \\
\hline Serratia ficaria CDC $1165-77$ & 20 & & \\
\hline Erwinia stewartii ATCC 8199 & 20 & & \\
\hline Buttiauxella agrestris CDC 1180-81 & 20 & & \\
\hline Edwardsiella tarda CDC $3592-64$ & 20 & & \\
\hline Erwinia cypripedii $\mathrm{EC} 155$ & 19 & & \\
\hline Erwinia carotovora ATCC 15713 & 19 & & \\
\hline Escherichia blattae CDC $9005-74$ & 19 & & \\
\hline Erwinia rubrifaciens ER105 & 18 & & \\
\hline Enterobacter agglomerans CDC 1620-71 & 18 & & \\
\hline Escherichia hermannii CDC 980-72 & 18 & & \\
\hline Leminorella grimontii 1944-81 & 18 & & \\
\hline Shigella flexneri CDC 2746-71 & 18 & & \\
\hline Erwinia carnegieana $\mathrm{EC} 186$ & 17 & & \\
\hline Erwinia mallotivora ATCC 2851 & 17 & & \\
\hline Erwinia quercina $\mathrm{EQ} 102$ & 17 & & \\
\hline Erwinia psidii CDC $435-84$ & 17 & & \\
\hline Enterobacter agglomerans CDC $1429-71$ & 17 & & \\
\hline Enterobacter agglomerans CDC 3482-71 & 17 & & \\
\hline Enterobacter agglomerans CDC 6070-69 & 17 & & \\
\hline Obesumbacterium proteus CDC $4302-74$ & 17 & & \\
\hline
\end{tabular}


TABLE 1-Continued

\begin{tabular}{|c|c|c|c|}
\hline \multirow{2}{*}{ Source of unlabeled DNA ${ }^{a}$} & \multicolumn{3}{|c|}{ Labeled DNA from Enterobacter pyrinus KCTC $2520^{\mathrm{T}}$} \\
\hline & $\begin{array}{l}\text { Relative binding } \\
\text { ratio at } 60^{\circ} \mathrm{C}^{b}\end{array}$ & $\begin{array}{c}\% \\
\text { Divergence }^{b}\end{array}$ & $\begin{array}{l}\text { Relative binding } \\
\text { ratio at } 75^{\circ} \mathrm{C}\end{array}$ \\
\hline Erwinia salicis ATCC 15712 & 16 & & \\
\hline Erwinia uredovora CDC $9574-82$ & 16 & & \\
\hline Escherichia coli $\mathrm{K}-12$ & 16 & & \\
\hline Erwinia tracheiphila ATCC 33245 & 15 & & \\
\hline Erwinia atroseptica ATCC 33260 & 15 & & \\
\hline Erwinia carotovora subsp. atroseptica ATCC 496 & 15 & & \\
\hline Ewingella americana $\mathrm{CDC} 1468-78$ & 15 & & \\
\hline Klebsiella ozaenae CDC 1660-71 & 15 & & \\
\hline Leminorella richardii CDC $978-82$ & 15 & & \\
\hline Rahnella aquatilis CDC 1327-79 & 12 & & \\
\hline Yersinia ruckeri CDC 4535-69 & 12 & & \\
\hline Enwinia carotovora subsp. wasabiae ATCC 43316 & 11 & & \\
\hline Erwinia carotovora subsp. betavascularum ATCC 8061 & 11 & & \\
\hline Hafnia alvei CDC $5632-72$ & 11 & & \\
\hline Budvicia aquatica CDC 440-84 & 11 & & \\
\hline Morganella monganii ATCC 25830 & 11 & & \\
\hline Enterobacter agglomerans CDC 1645-71 & 10 & & \\
\hline Yersinia enterocolitica CDC $497-70$ & 10 & & \\
\hline Yokenella regensburgei CDC $329-73$ & 10 & & \\
\hline Tatumella ptyseos CDC $\mathrm{H} 36$ & 8 & & \\
\hline Xenorhabdus luminescens CDC $9016-80$ & 6 & & \\
\hline Providencia rustigiani CDC $2896-68$ & 6 & & \\
\hline Xenorhabdus nematophilus CDC $9012-80$ & 5 & & \\
\hline Moellerella wisconsensis CDC 2896-78 & 5 & & \\
\hline Proteus mirabilis CDC PR14 & 5 & & \\
\hline Providencia alcalifaciens CDC $3370-67$ & 5 & & \\
\hline Providencia rettgeri ATCC 1163 & 5 & & \\
\hline Providencia stuartii CDC 132-68 & 4 & & \\
\hline
\end{tabular}

${ }^{a}$ ATCC, American Type Culture Collection, Rockville, Md.; CDC, Centers for Disease Control, Atlanta, Ga.; KCTC, Korean Collection for Type Cultures, Korea Institute of Science and Technology, Daejeon, Korea; IP, Institut Pasteur, Paris, France.

${ }^{b}$ Relative binding ratios were calculated as follows: (percentage of heterologous DNA bound to hydroxyapatite/percentage of homologous DNA bound to hydroxyapatite) $\times 100$. The relative binding ratios and divergence values are averages from at least two experiments.

c - , a blank space indicates that the reaction was not done.

\section{RESULTS}

The $\mathrm{G}+\mathrm{C}$ contents were as follows: $57.5 \mathrm{~mol} \%$ for strain KCTC $2520^{\mathrm{T}}$; $58.5 \mathrm{~mol} \%$ for strains KCTC 2585, KCTC 2586, KCTC 2587, and KCTC 2589; $60 \mathrm{~mol} \%$ for strain KCTC 2588; and 61 mol\% for strain KCTC 2590.

The levels of relatedness between labeled DNA from strain KCTC $2520^{\mathrm{T}}$ and unlabeled DNAs from the six other pear leaf strains and from type or reference strains of 89 genospecies belonging to the family Enterobacteriaceae are shown in Table 1. The average level of relatedness of the pear leaf strains was $97.5 \%$ in both 60 and $75^{\circ} \mathrm{C}$ reactions. There was no evidence of divergence within the related sequences. DNA from strain KCTC $2520^{\mathrm{T}}$ exhibited $46 \%$ relatedness to Enterobacter gergoviae IP $76.01^{\mathrm{T}}$ DNA and was $37 \%$ or less related to the DNAs of all of the other members of the Enterobacteriaceae tested (Table 1).

All of the strains of pear leaf bacteria were gram-negative, straight rods (0.6 to 1.1 by 1.6 to $2.3 \mu \mathrm{m})$ and were facultatively anaerobic. The cells were motile and peritrichous; four to six flagella were usually discernible (Fig. 1). After $48 \mathrm{~h}$ of incubation on nutrient agar, the pear leaf bacteria formed yellowish white, circular, convex, smooth, translucent, butyrous colonies that were approximately 1.5 to $4.0 \mathrm{~mm}$ in diameter. The seven strains were homogeneous in their physiological and biochemical properties, which are listed below in the description of the new species.

Biochemically and physiologically, the pear leaf strains were most similar to strains of Enterobacter gergoviae,
Enterobacter aerogenes, Erwinia cypripedii, and Erwinia rhapontici (Table 2). The pear leaf strains were differentiated from Enterobacter gergoviae by their ability to produce $\mathrm{H}_{2} \mathrm{~S}$, to grow in $\mathrm{KCN}$ broth, and to ferment myo-inositol and by their inability to ferment raffinose. Reactions that differentiate the pear leaf strains from their other closest phenotypic relatives are shown in Table 2.

\section{DISCUSSION}

The seven strains isolated from pear brown leaf spots were homogeneous in their biochemical characteristics and $\mathrm{G}+\mathrm{C}$

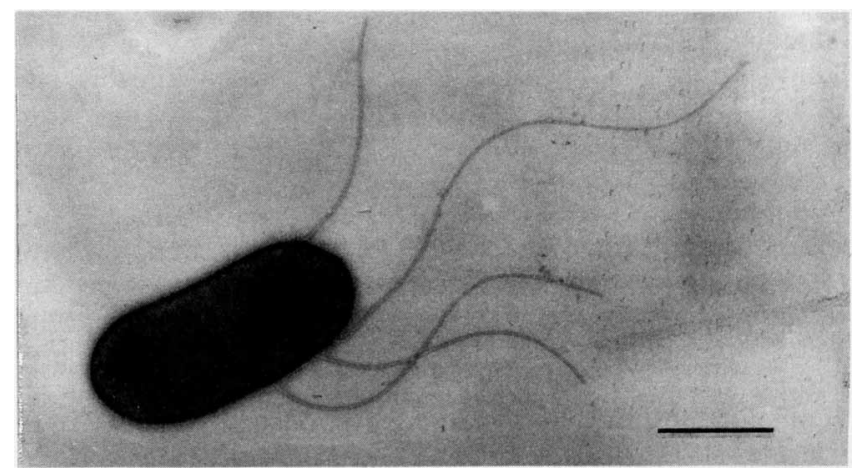

FIG. 1. Electron micrograph of a negatively stained cell of Enterobacter pyrinus $\mathrm{KCTC} 2520^{\mathrm{T}}$. Bar $=1 \mu \mathrm{m}$. 
TABLE 2. Biochemical and physiological characteristics of Enterobacter pyrinus and biochemically similar species

\begin{tabular}{|c|c|c|c|c|c|}
\hline Characteristic & $\begin{array}{c}\text { Enterobacter } \\
\text { pyrinus }\end{array}$ & $\begin{array}{c}\text { Enterobacter } \\
\text { gergoviae }^{a}\end{array}$ & $\begin{array}{l}\text { Enterobacter } \\
\text { aerogenes }^{a}\end{array}$ & $\begin{array}{c}\text { Enwinia } \\
\text { cypripedii }^{a}\end{array}$ & $\begin{array}{l}\text { Erwinia } \\
\text { rhapontici }\end{array}$ \\
\hline Motility & $+^{b}$ & + & + & + & + \\
\hline Pink pigment & - & - & - & - & + \\
\hline Yellow pigment & - & - & - & - & - \\
\hline Gas produced from D-glucose & + & + & + & + & - \\
\hline Nitrate reduction & + & + & + & + & + \\
\hline Indole production & - & - & - & - & - \\
\hline Voges-Proskauer test & + & + & + & - & + \\
\hline Growth in $\mathrm{KCN}$ broth & + & - & + & + & + \\
\hline Urease activity & + & + & - & - & - \\
\hline Gelatin liquefaction & - & - & - & - & - \\
\hline \multicolumn{6}{|l|}{ Acid produced from: } \\
\hline Melibiose & + & + & + & + & + \\
\hline myo-Inositol & + & - & + & + & + \\
\hline Raffinose & - & + & + & - & + \\
\hline Inulin & - & ND & ND & - & - \\
\hline Starch & - & ND & ND & - & - \\
\hline Maltose & + & + & + & + & + \\
\hline L-Arabinose & + & + & + & + & + \\
\hline D-Sorbitol & - & - & + & + & + \\
\hline Ribose & + & ND & ND & + & + \\
\hline Mannose & + & + & + & + & + \\
\hline D-Mannitol & + & + & + & + & + \\
\hline Cellobiose & + & + & + & + & + \\
\hline Lactose & - & $\mathrm{d}$ & + & - & + \\
\hline L-Rhamnose & + & + & + & + & + \\
\hline Esculin & + & + & + & + & + \\
\hline Salicin & + & + & + & + & + \\
\hline D-Xylose & + & + & + & + & $\mathbf{w}$ \\
\hline Trehalose & + & + & + & + & + \\
\hline Dulcitol & - & - & - & - & - \\
\hline Glycerol & + & ND & ND & $\mathrm{d}$ & + \\
\hline Sucrose & + & + & + & - & $\mathbf{w}$ \\
\hline Adonitol & - & - & + & - & + \\
\hline Dextrin & - & ND & ND & - & - \\
\hline Melezitose & - & ND & ND & - & + \\
\hline$\alpha$-Methyl-D-glucoside & - & - & + & - & + \\
\hline \multicolumn{6}{|l|}{ Utilization of: } \\
\hline Citrate (Simmons) & + & + & + & + & + \\
\hline L-Tartrate & - & ND & ND & + & - \\
\hline Malonate & + & + & + & $\mathrm{d}$ & + \\
\hline Galacturonate & + & ND & + & + & + \\
\hline $\mathrm{H}_{2} \mathrm{~S}$ production ${ }^{c}$ & + & - & - & + & + \\
\hline DNase activity & - & - & - & - & - \\
\hline Phenylalanine deaminase activity & - & - & - & + & - \\
\hline
\end{tabular}

${ }^{a}$ Data from reference 1.

$b+, 80 \%$ or more of the strains are positive;,$- 20 \%$ or less of the strains are positive; $d, 21$ to $79 \%$ of the strains are positive; w, weak reaction; ND, insufficient or no data.

c Data for Enterobacter gergoviae and Enterobacter aerogenes are results obtained on triple sugar iron agar, and the reactions of the Erwinia species were determined by using cysteine.

contents, which fell within the phenotypic definition of the family Enterobacteriaceae. These strains were closely related as determined by DNA hybridization. Therefore, both phenotypically and genetically, these strains represent a single species.

Phenotypically, the pear brown leaf spot strains can be differentiated from their closest relatives by four or more tests. The levels of DNA relatedness between pear brown leaf spot strain KCTC $2520^{\mathrm{T}}$ and 89 strains representing other species of the Enterobacteriaceae were in all cases less than $50 \%$, a value far lower than the level of relatedness recommended for phylogenetic definition of a species $(70 \%$ or more) (17). These data confirm that the pear brown leaf spot strains constitute a new species.

Because these strains are the causative agent of brown leaf spot disease in pear trees, it was natural to consider classifying them in the genus Erwinia, the genus that contains phytopathogenic species of the Enterobacteriaceae (8). It has been known for a long time that the genus Erwinia is phenotypically and genetically heterogeneous and that the boundary separating the genera Erwinia and Enterobacter is quite subjective $(1-4,7,11,12,16)$. A number of species originally classified in the genus Erwinia have now been reclassified in other genera, most notably the genus Enterobacter and the new genus Pantoea $(4,9,12)$. For purposes of comparison with previous work, strains belonging to the Enwinia herbicola-Enterobacter agglomerans group, some of which have now been reclassified in the genus Pantoea, are referred to in Table 1 as Enterobacter agglomerans hybridization groups I to XIII (2). DNA hybridization stud- 
ies showed that the pear brown leaf spot strains are most closely related to Enterobacter gergoviae (6). Therefore, we propose the name Enterobacter pyrinus sp. nov. for the pear brown leaf spot strains.

Description of Enterobacter pyrinus sp. nov. Enterobacter pyrinus (pyr' i.nus. N. L. n. pyrus, pear; L. suff. -inus, belonging to; N. L. adj. pyrinus, from pears). Cells are gram-negative, oxidase-negative, catalase-positive, fermentative rods ( 0.6 to 1.0 by 1.6 to $2.3 \mu \mathrm{m})$ that are motile and peritrichous. Grows well on nutrient agar, yeast extractdextrose- $\mathrm{CaCO}_{3}$ agar, and other common bacteriological media. Colonies on nutrient agar are circular, entire, convex, smooth, translucent, and 1.5 to $5.0 \mathrm{~mm}$ in diameter after $48 \mathrm{~h}$ of incubation at $27^{\circ} \mathrm{C}$. Growth occurs at $36^{\circ} \mathrm{C}$ and in the presence of $5 \%(\mathrm{wt} / \mathrm{vol}) \mathrm{NaCl}$. Positive in tests for acetoin production (Voges-Proskauer test), $\mathrm{H}_{2} \mathrm{~S}$ production from cysteine, gluconate oxidation, gas production from D-glucose, $\mathrm{KCN}$ tolerance, nitrate reduction, phosphatase activity, reducing substances produced from sucrose, and urease activity. Negative in tests for casein hydrolysis, DNase activity, erythromycin susceptibility, gelatin liquefaction, growth factor requirement, indole production, mucoid growth, pectinase activity, phenylalanine deaminase activity, pigment production, potato rot, and tobacco hypersensitivity. The strains utilize citrate, formate, lactate, galacturonate, and malonate as sole carbon sources, but not L-tartrate. Acid is produced from L-arabinose, cellobiose, esculin, glycerol, myo-inositol, maltose, D-mannitol, mannose, melibiose, ribose, L-rhamnose, salicin, trehalose, and $\mathrm{D}$-xylose. Acid is not produced from adonitol, dextrin, dulcitol, inulin, lactose, melezitose, $\alpha$-methyl-D-glucoside, palatinose, raffinose, D-sorbitol, and starch. Phenotypic tests that are useful for differentiating Enterobacter pyrinus from other Enterobacter and Erwinia species are shown in Table 2.

The $\mathrm{G}+\mathrm{C}$ content of the DNA is 57.5 to $61 \mathrm{~mol} \%$ (as determined by the thermal denaturation method).

Strains were isolated from pear leaves and cause brown leaf spot disease of pear trees ( $P$. pyrifolia Nakai).

Description of the type strain. The type strain of Enterobacter pyrinus is strain KCTC 2520 (= CDC $6570=$ ATCC 49851). This strain was isolated from diseased pear ( $P$. pyrifolia cv. Mansamgil) leaves at Yusung, Korea, in 1988. The biochemical characteristics of this strain are identical to those of the species, and the $\mathrm{G}+\mathrm{C}$ content of its DNA is 57.5 $\mathrm{mol} \%$.

\section{ACKNOWLEDGMENTS}

We thank Kyung Sook Bae at the Korean Collection for Type Cultures for providing the pear leaf strains and Joon Seong Lee for the electron micrograph.

\section{REFERENCES}

1. Brenner, D. J. 1984. Family Enterobacteriaceae Rahn 1937, Nom. fam. Cons. Opin. 15, Jud. Comm. 1958, 73; Ewing, Farmer, and Brenner 1980, 674; Judicial Commission 1981, 104, p. 408-420. In N. R. Krieg and J. G. Holt (ed.), Bergey's manual of systematic bacteriology, vol. 1. The Williams \& Wilkins Co., Baltimore.

2. Brenner, D. J., G. R. Fanning, J. K. Leete Knutson, A. G. Steigerwalt, and M. I. Krichevsky. 1984. Attempts to classify herbicola group-Enterobacter agglomerans strains by deoxyribonucleic acid hybridization and phenotypic tests. Int. J. Syst. Bacteriol. 34:45-55.

3. Brenner, D. J., G. R. Fanning, and A. G. Steigerwalt. 1974. Deoxyribonucleic acid relatedness among erwiniae and other Enterobacteriaceae: the gall, wilt, and dry necrosis organisms (genus Erwinia Winslow et al., sensu stricto). Int. J. Syst. Bacteriol. 24:197-204.

4. Brenner, D. J., A. McWhorter, A. Kai, A. G. Steigerwalt, and J. J. Farmer III. 1986. Enterobacter asburiae: a new species found in human clinical specimens, and reassignment of Erwinia dissolvens and Erwinia nimipressuralis to the genus Enterobacter as Enterobacter dissolvens comb. nov. and Enterobacter nimipressuralis comb. nov. J. Clin. Microbiol. 23:1114-1120.

5. Brenner, D. J., A. C. McWhorter, J. K. Leete Knutson, and A. G. Steigerwalt. 1982. Escherichia vulneris: a new species of Enterobacteriaceae associated with human wounds. J. Clin. Microbiol. 15:1133-1140.

6. Brenner, D. J., C. Richard, A. G. Steigerwalt, M. A. Asbury, and M. Mandel. 1980. Enterobacter gergoviae sp. nov.: a new species of Enterobacteriaceae found in clinical specimens and the environment. Int. J. Syst. Bacteriol. 30:1-6.

7. Brenner, D. J., A. G. Steigerwalt, G. V. Miklos, and G. R. Fanning. 1973. Deoxyribonucleic acid relatedness among erwiniae and other Enterobacteriaceae: the soft-rot organisms (genus Pectobacterium Waldee). Int. J. Syst. Bacteriol. 23:205-216.

8. Chung, Y. R., B. S. Kim, H. T. Kim, and K. Y. Cho. 1990. Erwinia pirina sp. nov., a causal organism of brown leaf spot of pear. Korean J. Plant Pathol. 6:311.

9. Gavini, F., J. Mergaert, A. Beji, C. Mielcarek, D. Izard, K. Kersters, and J. De Ley. 1989. Transfer of Enterobacter agglomerans (Beijerinck 1888) Ewing and Fife 1972 to Pantoea gen. nov. as Pantoea dispersa sp. nov. Int. J. Syst. Bacteriol. 39:337-345.

10. Hong, K. H., Y. S. Kim, W. C. Kim, and E. J. Lee. 1985. Studies on the abnormal spot disease of pear leaves. Res. Rep. Rural Dev. Admin. (Hortic.) (Suwon) 27:46-55.

11. Lelliott, R. A. 1974. Genus XII. Enwinia Winslow, Broadhurst, Buchanan, Krumweide, Rogers and Smith, 1920, 209, p. 332339. In R. E. Buchanan and N. E. Gibbons (ed.), Bergey's manual of determinative bacteriology, 8th ed. The Williams \& Wilkins Co., Baltimore.

12. Lelliott, R. A., and R. S. Dickey. 1984. Genus VII. Erwinia Winslow, Broadhurst, Buchanan, Krumweide, Rogers and Smith 1920, 209, p. 469-476. In N. R. Krieg and J. G. Holt (ed.), Bergey's manual of systematic bacteriology, vol. 1 . The Williams \& Wilkins Co., Baltimore.

13. Marmur, J., and P. Doty. 1962. Determination of the base composition of deoxyribonucleic acid from its thermal denaturation temperature. J. Mol. Biol. 5:109-118.

14. Schaad, N. W. 1988. Laboratory guide for identification of plant pathogenic bacteria, 2nd ed. The American Phytopathological Society, St. Paul, Minn.

15. Smibert, R. M., and N. R. Krieg. 1981. General characterization, p. 409-433. In P. Gerhardt, R. G. E. Murray, R. N. Costilow, E. W. Nester, W. A. Wood, N. R. Krieg, and G. B. Phillips (ed.), Manual of methods for general bacteriology. American Society for Microbiology, Washington, D.C.

16. Steigerwalt, A. G., G. R. Fanning, M. A. Fife-Asbury, and D. J. Brenner. 1976. DNA relatedness among species of Enterobacter and Serratia. Can. J. Microbiol. 22:121-137.

17. Wayne, L. G., D. J. Brenner, R. R. Colwell, P. A. D. Grimont, O. Kandler, M. I. Krichevsky, L. H. Moore, W. E. C. Moore, R. G. E. Murray, E. Stackebrandt, M. P. Starr, and H. G. Trüper. 1987. Report of the Ad Hoc Committee on Reconciliation of Approaches to Bacterial Systematics. Int. J. Syst. Bacteriol. 37:463-464. 